Article

\title{
Vocabulary Teaching Practices of L2 English in Upper Secondary Vocational Classrooms
}

\author{
Kaja Granum Skarpaas*(D) and Kari Anne Rødnes
}

check for updates

Citation: Skarpaas, Kaja Granum, and Kari Anne Rødnes. 2022. Vocabulary Teaching Practices of L2 English in Upper Secondary Vocational Classrooms. Languages 7: 55. https://doi.org/10.3390/ languages7010055

Academic Editors: Pia Sundqvist, Erica Sandlund, Marie Källkvist and Henrik Gyllstad

Received: 30 October 2021 Accepted: 21 February 2022 Published: 1 March 2022

Publisher's Note: MDPI stays neutral with regard to jurisdictional claims in published maps and institutional affiliations.

Copyright: (C) 2022 by the authors. Licensee MDPI, Basel, Switzerland. This article is an open access article distributed under the terms and conditions of the Creative Commons Attribution (CC BY) license (https:// creativecommons.org/licenses/by/ $4.0 /)$.

\author{
Department of Teacher Education and School Research, University of Oslo, 0315 Oslo, Norway; \\ k.a.rodnes@ils.uio.no \\ * Correspondence: k.g.skarpaas@ils.uio.no
}

\begin{abstract}
This qualitative study investigates language teaching practices relating to L2 English vocabulary instruction in upper secondary school vocational classrooms in Norway. It builds on previous research describing technical vocabulary as an area of particular importance for vocational students ${ }^{\prime}$ English language development and relies on observation data from eight vocational classrooms. The study found that vocabulary work has a strong presence within vocational orientation (VO) instruction, across whole-class instruction, group or pair work, and individual work. Most target vocabulary could be classified as words relating to work practices and vocational content knowledge. Many instances of L1-L2 translation tasks were observed. Target words were not practiced across the four language skills and were rarely utilized in productive tasks. The study concludes that observed practices can be improved by prioritizing ways of combining target vocabulary with students' language production and by including more opportunities to practice independent language strategies.
\end{abstract}

Keywords: vocabulary; L2 English; vocational students; vocational orientation approach

\section{Introduction}

In this study, we examine language practices relating to English vocabulary instruction in a context rarely encountered in the research literature: the upper secondary vocational classroom. The study was conducted in Norway, where English is a de facto, but not a de jure, second language (L2) taught from the very first school year (see Rindal and Brevik 2019 for a discussion on the status of English in Norway). In year eleven, approximately half the students enter a vocational upper secondary program, where they study both vocationspecific subjects and general subjects. In addition to English (L2), the general subjects comprise Norwegian (L1), mathematics, natural science, physical education, and social science) (Norwegian Directorate for Education and Training [UDIR] 2020).

Language competence, including L2 English, is important in all sectors in today's global society (Hellne-Halvorsen et al. 2021), and English is, therefore, an essential part of the general knowledge that vocational students need to complement their domain-specific learning (Brewer and Comyn 2015; Hiim 2014; Mouzakitis 2010; Sweet 2010). Still, some have argued that general subjects have little relevance for vocational students' educational needs and interests (Abbott 1997; European Centre for the Development of Vocational Training (CEDEFOP) (2019); Grubb 2006; Hiim 2017) and, for this reason, that they become a main source of demotivation. To make general subjects more appealing to vocational students, stakeholders within educational research and policy call for more relevant instruction that is contextualized within a vocational frame (Conroy and Walker 2000; European Centre for the Development of Vocational Training (CEDEFOP) (2019); Hoachlander 1999; NOU 2008:18 2008; Quinn 2013; Roberts et al. 2005; Vogt and Kantelinen 2012). In Norway, this is achieved through what is known as a vocational orientation (VO) to teaching. It denotes a teaching practice within upper secondary school where general subjects are adapted to vocational programs in terms of content and methods while building on a generalized 
curriculum that is common to all programs (Norwegian Directorate for Education and Training [UDIR] 2019; Regulations of the Education Act 2006). As the upper secondary vocational programs in Norway are quite broad (even in year 12) and may qualify for higher education, VO teaching must extend the needs of specific occupations. Therefore, VO is not as targeted as English for specific purposes (ESP), where the focus on a particular group is much more distinct (Hyland 2007). It is also distinct from content- and language-integrated teaching (CLIL), where the English language is the medium of instruction and not, as such, the object of study (see, for example, Coyle 2010).

A previous interview study from Norway $(N=10)$ found that English teachers viewed VO teaching as a tool to increase vocational students' engagement with L2 English (Skarpaas and Hellekjær 2021). The teachers explained the success of VO by saying that the method draws on student interest, promotes subject relevance, and scaffolds learning. According to the teachers, vocabulary has an important role to play in the success of VO because the technical words become testimonies of relevant instruction. That study did not, however, explore instruction. Therefore, in the current study, we investigate how English vocabulary is taught under a VO heading to better understand the role it plays in this teaching approach. To that end, the study uses observations from eight classrooms in a Norwegian upper secondary school.

\subsection{Background}

Words are the building blocks of language, and vocabulary knowledge is thus a crucial part of language learning. Vocabulary size is positively associated with learners' reading, writing, and listening proficiency (Chung and Nation 2003; Cobb 2007; Laufer and Ravenhorst-Kalovski 2010; Shi and Qian 2012; Stæhr 2008), while vocabulary errors can bring about misunderstandings that interrupt the flow of communication (Johansson 1978; Llach 2011; Qian and Lin 2020). Vocabulary knowledge includes both receptive and productive abilities, and to know a word learners must become familiar with its form, meaning, and use (Nation 2001, p. 27). A common suggestion is to learn words according to their frequency in the initial phase of language learning, prioritizing the more common, and thus more useful, words first. Later, when every new addition is a word that is infrequently spoken or written, it makes more sense to learn according to need (Schmitt and Schmitt 2020).

For vocational students in upper secondary education, it is important to develop a repertoire of words related to work, referred to as technical vocabulary. Technical vocabulary, or words and phrases that are mainly used in a specific profession, trade, or subject area (Chung and Nation 2003, 2004; Liu and Lei 2020; Nation 2001), is an essential part of the language of work and an important tool for workers' professional communication (Knoch 2014). Technical vocabulary accounts for up to thirty percent of word tokens in technical texts (Chung and Nation 2003) and is thus indispensable for comprehension (Woodward-Kron 2008). However, it denotes more than "just words," as it represents the concepts and ideas specific to a particular domain (Chung and Nation 2004; Schmitt and Schmitt 2020) and provides the language needed to express key practices within a particular field (Chung and Nation 2003).

Teaching vocational topics and vocabulary may pose a challenge for language teachers, who generally lack vocational insight (Widodo 2016). However, since technical vocabulary has a limited range of use (Liu and Lei 2020), students are unlikely to acquire this L2 repertoire incidentally (Coxhead 2018), and language teachers have an important role to play.

\subsubsection{Principles for Teaching Vocabulary}

Two major learning conditions for vocabulary teaching are number of encounters and quality of attention (Webb and Nation 2017): words have a greater likelihood of being learned after multiple encounters (Webb and Chang 2015)_preferably in a variety of contexts (Nation 2017) — and when students actively engage in accompanying learning activities (Hulstijn and Laufer 2001; Laufer and Hulstijn 2001). It is also important for 
retention that words are re-encountered quickly (Webb and Chang 2015), preferably during the same lesson (Schmitt 2017). Furthermore, to facilitate optimal learning conditions, Nation $(2001,2007,2020 a)$ suggests that teachers make sure their students encounter target vocabulary across the four language skills (listening, speaking, reading, writing) as well as the four strands of language learning (meaning-focused input, meaning-focused output, language-focused learning and fluency development) that typically make up a well-balanced language course.

Much of the research on L2 vocabulary comes from the English as a foreign language (EFL) context, where students have limited target language contact outside of school. However, in Norway, English is everywhere (Cabau 2009; Rindal 2014) and central to people's life worlds (Brevik and Holm, forthcoming; Sundqvist and Sylvén 2016). This matters because Norwegian children, as children in several other European countries (De Wilde and Eyckmans 2017; Jensen 2017; Kuppens 2010; Lindgren and Muñoz 2013), start school already knowing substantial amounts of English. Their vocabulary size quickly exceeds that of students in EFL contexts with years of schooling behind them (Laufer 2010). Webb and Nation (2017) argue that in contexts where English is ubiquitous, and learners have many opportunities to learn independently, it is imperative that they become capable of using this favorable circumstance to their advantage. Thus, an important goal of classroom instruction must be to teach vocabulary learning strategies and to support students as autonomous language learners both inside and outside the classroom (Nation 2001; Schmitt 2017).

English teachers in vocational programs must take into consideration the vocational aspect of their students' educational choices. However, historically, it has been argued that language teachers are unprepared for the teaching of technical vocabulary (e.g., Cowan 1974). One reason is that language teachers' lack of domain knowledge impedes their ability to comprehend technical terms (Webb and Nation 2017). This complication extends to students, for whom technical terms will not make much sense before they know the accompanying theory or practice (Nagy and Townsend 2012; Widodo 2016). In other words, language teachers need access to the content of their students' vocational subjects in order to coordinate instruction. Skarpaas and Hellekjær (2021) found that for English teachers in Norway, gaining access is not always easy as they rarely have the opportunity to collaborate or confer with their vocational colleagues.

For language teachers who are uncomfortable teaching technical terms, it has been suggested that they can engage learners in identifying what words are central to a specific topic or area (Alcina 2011; Fernádez et al. 2009). Instead of trying to become vocational authorities, language teachers can concentrate on their role as language experts and help learners become aware and develop their repertoire of vocabulary strategies (Chung and Nation 2003) and support their students' language awareness and ability to recognize technical terms (Nation 2001).

\subsubsection{Research Aim}

The present study aims to describe the characteristics of vocabulary work within a vocational orientation approach to the teaching of L2 English in secondary school vocational classrooms. It focuses on explicit opportunities for vocabulary learning because these are episodes that may be observed. We will compare some current teaching practices to theory and previous research to further illuminate the appeal and importance of vocabulary work within $\mathrm{VO}$ teaching.

\section{Design and Methods}

\subsection{Educational Context}

In Norway, half the student population enters a vocational program in upper secondary school (Norwegian Directorate for Education and Training [UDIR] 2021). Most such programs consist of two years in school (years 11 and 12), followed by a two-year apprenticeship. After completing their apprenticeships, students qualify for craft certificates, or 
they may add a third year in school to qualify for higher education. All students (regardless of study program) are required to pass a general English course totaling 140 teaching hours. This course prioritizes communicative and intercultural competence, basic literacy skills, and cultural and social content knowledge. Learning vocabulary is not an isolated goal but is linked to communication and language production (Norwegian Directorate for Education and Training [UDIR] 2006, 2019). Mostly, English classes are organized by program so that all students in one class attend, for instance, the Building and Construction program. This was the case for all classes in our study.

It is mandatory for all general subject teachers (including English teachers) to apply a vocational orientation approach to their teaching, but they enjoy substantial freedom in determining how and when.

\subsection{Research Procedure}

This qualitative study relies on non-participatory observation data that was collected as part of a larger project with ten teacher participants. In the larger project, we utilized a purposive sampling strategy with three selection criteria to identify schools eligible for participation:

1. an expressed commitment to $\mathrm{VO}$ teaching,

2. a vocational identity, and

3. a geographical location in eastern or western Norway to ensure some geographical spread. The researcher's travel time could not exceed two hours in eastern Norway, and schools in western Norway had to be accessible by airplane and public transportation.

We utilized county administration websites to obtain lists of all upper secondary schools with vocational study programs in our target locations $(N=146)$. Next, by examining school websites, we identified 22 suitable schools. The 22 schools were contacted, and ten teachers from ten of these schools volunteered to participate.

From May 2018 to April 2019, the first author collected data in the ten vocational English classrooms, including observations and student- and teacher interviews. Her observations, which are the data utilized in this study, comprised one cohesive teaching trajectory per classroom, lasting from two to five lessons (180-450 min), and, in total, 23 lessons are included in the material. The teaching trajectories were planned by the instructing teacher, who defined them as typical examples of their VO teaching. While the aforementioned interviews were not analyzed for this particular study, they have been analyzed for other purposes (Skarpaas and Hellekjær 2021) and have informed our analysis in the present study.

During the observed lessons, the first author took detailed, naturalistic observation notes focusing on the activities that the teachers initiated, describing (if applicable) expressed purposes and/or intended learning outcomes, tasks, learning materials, organization, and use of time. In addition, she wrote down several examples of dialogue between teachers and students, aiming to capture exact renderings of the exchanges. When she was unable to do this, she would make a note of it in her document and instead paraphrase what was being said to capture content. Example extracts of field notes are available in Appendix A. Table 1 includes information on the number of observations we conducted in each classroom.

\subsection{Participants}

The student participants in this study were all pre-service and living in Norway. They were between the ages of 16-20. The teachers had between 3-25 years of experience and were all trained English language teachers. All but one teacher (S6) reported very little collaboration with vocational colleagues when asked by the researchers about this relationship.

Table 1 provides an overview of participating classrooms, including what year (level) they represent, the number of students per class, and the number and minutes of observed 
lessons. In Norway, the English subject in upper secondary school amounts to 140 teaching hours with no requirement in terms of individual lesson length. The lessons observed in this material ranged from 90-145 $\mathrm{min}$.

Table 1. A table representing the participating classrooms.

\begin{tabular}{cccc}
\hline School & Year (Level) & No. Students * & $\begin{array}{c}\text { No./min. of Observed } \\
\text { Lessons }\end{array}$ \\
\hline S1 & 11 & 13 & $3 / 180 \mathrm{~min}$. \\
S2 & 11 & 14 & $2 / 290 \mathrm{~min}$. \\
S3 & 12 & 15 & $5 / 450 \mathrm{~min}$. \\
S4 & 12 & 10 & $2 / 180 \mathrm{~min}$. \\
S5 & 11 & 14 & $3 / 270 \mathrm{~min}$. \\
S6 & 11 & 13 & $2 / 240 \mathrm{~min}$. \\
S7 & 11 & 14 & $4 / 360 \mathrm{~min}$. \\
S8 & 11 & 11 & $2 / 270 \mathrm{~min}$. \\
S9 & 12 & 15 & $2 / 180 \mathrm{~min}$. \\
S10 & 12 & & $4 / 360 \mathrm{~min}$. \\
\hline
\end{tabular}

${ }^{*}$ In Norway, vocational classes usually take up to 15 students.

As shown in Table 1, six classes were in Year 11 and four in Year 12. The main difference between Years 11 and 12 was that students in Year 11 attended a broader foundation course, while students in Year 12 had selected a more specialized course within their field. We, therefore, make the assumption that in terms of vocational learning, year 12 students will possess more specialized knowledge than their younger peers.

\subsection{Data Analysis}

To investigate the characteristics of vocabulary work within a VO approach, we followed procedures anchored in thematic analysis (Braun and Clarke 2012; Terry et al. 2017). We started by familiarizing ourselves with the data. Individually, both researchers read and reread the observation notes (comprising 126 pages), highlighting and taking notes to identify potentially interesting items. After working individually with the material, we discussed our perceptions of salient features to develop initial descriptive codes concerning classroom activities. Some example codes include individual work, word choice, strategies, teacher explanations, and vocabulary use. In the next phase, we utilized NVivo to review the data and the initial codes to identify broader topics. Thus, we developed themes, or overarching categories, to capture patterns across classrooms. At this point, we also compared our developing themes to topics in the relevant research literature and prioritized them according to relevance. From reviewing and reorganizing, we derived the following main themes: Explicit/implicit attention to vocabulary, word choice, organization, and vocabulary context (further described in Appendix B). Through the first theme, explicit focus, we saw that eight classrooms (out of ten in total) prioritized vocabulary explicitly. We decided to limit our scope to these explicit instances, so while S9 and S10 were part of the initial analyzes, they were not part of the further exploration on account of not meeting the criteria explicit vocabulary attention.

\subsection{Ethics}

Throughout the project, caution was exercised to maintain the right to privacy, and the field notes prioritized the larger picture of "life in the classroom" rather than focusing on individuals. Participants have been anonymized, and all proper names in the material are pseudonyms.

\section{Findings}

In this section, we first characterize the material by presenting three central aspects: word choice, organization, and context (Section 3.1). Then, we present three snapshots (Section 3.2), or examples, which will illustrate variety across the material. These par- 
ticular snapshots were selected to illustrate practices of particular interest to language teaching/learning that were not easily captured in the cross-material characterizations of Section 3.1.

\subsection{Characteristics across the Material}

Table 2 provides a brief overview of our observations, including the two classrooms with no explicit vocabulary focus (S9 and S10) that were part of the overall project. Where applicable, it includes short descriptions of observed target vocabulary.

Table 2. A table describing observed instruction in S1-S10 and target vocabulary in S1-S8.

\begin{tabular}{ccc}
\hline School & Descriptions of Observed Instruction & Target Vocabulary \\
\hline S1 & $\begin{array}{c}\text { Students wrote instruction manuals for } \\
\text { how to operate certain machines. }\end{array}$ & $\begin{array}{c}\text { vocabulary related to the operation of } \\
\text { a machine }\end{array}$ \\
\hline S2 & $\begin{array}{c}\text { Students learned names of parts and } \\
\text { processes involved in constructing } \\
\text { all-terrain vehicles (ATVs) }\end{array}$ & $\begin{array}{c}\text { vocabulary needed to describe the } \\
\text { process of building ATVs }\end{array}$ \\
\hline
\end{tabular}

$\begin{array}{cc}\begin{array}{c}\text { First, students read about and discussed } \\ \text { vocational education. Next, they read } \\ \text { about and discussed safety at work and }\end{array} & \begin{array}{c}\text { vocabulary concerning the students' } \\ \text { wrote accident reports describing a } \\ \text { fictitious accident. }\end{array} \\ & \begin{array}{c}\text { own education + vocabulary } \\ \text { concerning workplace safety }\end{array}\end{array}$

\begin{tabular}{|c|c|c|}
\hline $\mathrm{S} 4$ & $\begin{array}{c}\text { First, students talked about a homework } \\
\text { reading. Then, they worked on } \\
\text { translation tasks. Finally, the teacher led a } \\
\text { whole class session where students } \\
\text { answered questions about their } \\
\text { translations. }\end{array}$ & $\begin{array}{l}\text { vocabulary to name various baked } \\
\text { goods and cereals }\end{array}$ \\
\hline S5 & $\begin{array}{l}\text { First, students discussed safety in the } \\
\text { workshop. Next, they listed and } \\
\text { translated vocabulary related to the } \\
\text { topic tools. }\end{array}$ & $\begin{array}{l}\text { vocabulary concerning workplace } \\
\text { safety + vocabulary concerning tools }\end{array}$ \\
\hline S6 & $\begin{array}{l}\text { First, students read about tools. Next, } \\
\text { they worked with comprehension tasks } \\
\text { and vocabulary related to the topic tools. }\end{array}$ & $\begin{array}{l}\text { vocabulary related to the tools in } \\
\text { the workshop }\end{array}$ \\
\hline
\end{tabular}

\begin{tabular}{|c|c|c|}
\hline S7 & $\begin{array}{c}\text { First, students discussed various relevant } \\
\text { occupations. Then, they wrote } \\
\text { manuscripts for a presentation } \\
\text { comparing two occupations in terms of } \\
\text { education and work tasks. }\end{array}$ & $\begin{array}{l}\text { vocabulary concerning vocational } \\
\text { education and career paths }\end{array}$ \\
\hline S8 & $\begin{array}{l}\text { First, students worked with vocabulary } \\
\text { related to youth work. Next, they } \\
\text { discussed the concept of a role model. } \\
\text { Then, they read and discussed a text } \\
\text { about nursing homes. }\end{array}$ & $\begin{array}{l}\text { current focus terms in the students' } \\
\text { vocational subject + vocabulary } \\
\text { concerning nursing homes }\end{array}$ \\
\hline S9 * & $\begin{array}{l}\text { Students wrote papers on British hair or } \\
\text { design history. }\end{array}$ & No target vocabulary \\
\hline $\mathrm{S} 10 *$ & $\begin{array}{l}\text { In groups, students prepared oral } \\
\text { presentations concerning music therapy } \\
\text { for dementia patients. }\end{array}$ & No target vocabulary \\
\hline
\end{tabular}

* No explicit vocabulary attention and therefore not explored in detail in this study.

Vocabulary received explicit attention in eight out of ten classrooms. Thus, we can establish that explicit attention to vocabulary is a common element within a vocational orientation approach to English, at least in the Norwegian school system. We will use the subsequent sections to characterize this instruction further. 


\subsubsection{Word Choices: What Words Were Attended to?}

Most of the target vocabulary could be classified as work-related. Examples were observed in all classrooms, except S7, and included words concerning the practices of relevant occupations, including tools, machines, safety gear, and produce-typically physical objects. In S5, for example, one of the observed activities involved listing hand tools the students had used as part of their vocational training.

In addition to the expected category of work-related vocabulary, our observations included two instances (in S3 and S7) of vocabulary that could be classified as relating to the system of vocational education. In both cases, the teachers included some of the same words, such as apprentice and vocational education, while other words differed.

To summarize, we found that all classrooms worked with specialized vocabulary, frequently of an occupational nature. More rarely, the words related to the system of vocational education. Table 2 above offers a brief description of the target vocabulary in each classroom.

\subsubsection{Organization}

We observed vocabulary work across all types of classroom organization-in wholeclass instruction, group or pair work, and individual work (Consult Appendix C for an overview). In sum, teacher-led whole-class conversations were the most common and were observed in all eight classrooms. Group or pair activities relating to vocabulary were observed in four classrooms, while individual activities were observed in all but one.

\section{Whole Class}

Whole-class instruction with vocabulary focus could be grouped into one of two categories. Most common were conversations with an explicit focus on word form and how to translate words from Norwegian into English. These whole-class conversations were predominantly examples of the initiation-response-feedback (IRF) format, where the teacher asks a question, a student answers, and the teacher accepts or corrects them. To illustrate, we have included an excerpt from S3, in which the teacher checked the students' vocabulary retention from a homework reading:

Teacher: What safety gear do you need to wear? Thomas?

Thomas: eh ... helmet

Teacher: Yes. We can also call this a hard hat

Lars: Vest ... I don't know what refleksvest [reflective vest] is called in English

Allan: High-visibility vest

Teacher: Yes, either that or reflective vest

Lars: Ear plugs

Ola: Protective glasses

Ali: Eller [or] goggles

T: Excellent. You have read the text and remember a lot of the vocabulary

In this excerpt, the teacher accepted the translations helmet and high-visibility vest as alternatives to hard hat and reflective vest, although the reading had included the latter pair only. Ali, however, corrected Ola's suggestion from protective glasses to goggles. Although not the case in this excerpt, it was quite common for the teachers to solicit a specific word when they asked for L1-L2 translations and to correct students who offered alternatives. Across the material, the teacher in S8 was the only one who actively encouraged students to discuss alternative translations, in this way displaying a broader understanding of words and their function.

The second type of whole-class instruction, observed in three classrooms (S1, S3, S7), involved meta-conversations about vocabulary. Here, the teachers addressed such issues as the function of the specific vocabulary in instruction manuals (S1) and the impact of 
vocabulary on grades (S3 and S7). These meta-conversations were highly structured by the teachers, who overall conveyed the message that appropriate vocabulary would improve the quality of a written or spoken text.

\section{Group and Pair Work}

In four classrooms, the students worked with vocabulary in groups or pairs. In two of these cases (S2 and S3), the pair/group activities concerned word-level translations in an online game. The game would only accept one translation as correct, and to play, the students would first have to memorize their teachers' translations.

In the other two examples of pair/groupwork (S6, S7), the activities required discussion beyond the word level. To illustrate, we will give an example from S6, where pairs of students translated an English textbook text into Norwegian. It was a spoken exercise, and the goal was to notice and learn new words and phrases. To aid their translations, the students used the textbook glossary as well as input from their teacher, who visited the groups one by one. The teacher also spent time asking the pairs how they had translated key terms, seemingly to check retention of central vocabulary.

\section{Individual Work}

Seven classrooms (all but S2) had one or more examples of students working individually with vocabulary. The word-level translation was the most common activity within the individual segment (observed in all seven instances). In S4, for example, the students were given a booklet with 43 baking-related words to be translated into English. In this example, the students worked independently to find appropriate translations, and they were not asked to use specific tools or strategies to complete the work. Many of the students used Google Translate, and at one point, the teacher felt the need to remind her students not to rely on this as a definitive tool for answers. However, she did not suggest other sources by which they could try to expand their strategic repertoire. In addition to Google Translate, we observed several instances where students asked the teacher to tell them the correct term. In these cases, the teacher performed as they asked by simply stating a translation.

To summarize, we mainly observed strong teacher regulation of whole class instances and standardized activities and task instructions in group/pair and individual activities. It was typical for the vocabulary work to be highly structured, and we observed many instances of L1-L2 translations across the organizational formats.

\subsubsection{Vocabulary Context}

In the observed trajectories, vocabulary episodes occurred in contexts of varying complexity. To describe this complexity, we need to account for two types of context: the inter-subject context, concerning links between the English instruction and the vocational subjects, and the intra-subject context, describing how vocabulary work relates to other tasks or activities within the English subject.

\section{Inter-Subject Context}

The inter-subject context concerns whether the observed instruction had expressed links to current (or past) units of the students' vocational subjects. In four classes (S1, S2, $\mathrm{S} 5, \mathrm{~S} 8$ ), the teacher addressed this relationship, thus making the vocational orientation explicit. In the other four classrooms (S3, S4, S6, S7), such links were not mentioned, leaving the vocational orientation implicit.

There were differences in how explicit inter-subject links played out in our observations. In S1 and S5, the students were required to use content knowledge from their vocational subjects to solve English language tasks. In S2 and S8, however, the students worked with relevant vocabulary, but they were not required to utilize knowledge or competence from their vocational subjects. In other words, thematic links that were created between English and the vocational subject were not sustained in the actual activities. 
In the four cases of implicit $\mathrm{VO}$, neither the teacher nor the students addressed any links between English and the actual (completed or ongoing) content of the students' vocational study programs. Furthermore, there was no evidence to suggest a planned link in our observation notes nor in the teacher interviews that were conducted as part of the overall research project (see Section 2.2). When we use the term implicit to describe this type of instruction, it is because there were still loose ties between the English teaching and the students' vocational subjects. We can illustrate the notion of implicit inter-subject links by referring to an example from S7. Here, students in year 11, which is a fairly broad foundation course, were to work with vocabulary to describe the educational path to their future occupation. Clearly, this had relevance, as the discussed occupations were genuine career options for the students. A problem, however,-and the reason we consider it an example of implicit inter-subject link - was that the students had not yet decided between the various year 12 specializations that existed in their field and did not know much about their options.

\section{Intra-Subject Context}

Descriptions of the intra-subject context of vocabulary activities concern how these activities figure within a larger English teaching trajectory. We have categorized the vocabulary work as examples of either separate or embedded activities.

In what we term separate activities, learning words was presented as a goal in its own right. Seven classrooms (not S1) had at least one example of a separate vocabulary task. Most often, the separate tasks asked the students to work with L1-L2 translation, concentrating on form. We have already described how this transpired in S4 (above, under individual work).

For some of the activities that we have categorized as separate, the teachers did address why the students should acquire the target vocabulary. In S2, for example, the teacher specified that the students were learning words that would be useful for a test later in the semester. However, in the observed lessons, the words were simply translated and not utilized for communication or other purposes. The activity has therefore been classified as separate.

In embedded activities, attention to words was framed as necessary for completing a larger task within the observed trajectory. The students would, for example, be instructed to use suitable vocabulary when writing a longer text, or there was attention to the role of vocabulary in reading comprehension tasks. Because the words occurred in a richer context (compared to the separate activities), there were more opportunities to pay attention to meaning and use.

The embedded tasks most frequently combined vocabulary with reading (S3, S4, S5, S6, S7, S8). Vocabulary figured in pre-reading activities as students previewed central vocabulary prior to reading. Twice, vocabulary was attended to in the while-reading stage, once as the teacher asked students to underline central terms while reading (S3), and once as students read a text in English, which they simultaneously translated into Norwegian (S6). The most common observation, however, was for vocabulary to figure in the post-reading phase, typically as a comprehension check. In S6, the post-reading activity concerned the pronunciation of challenging words that the students had noticed in their reading (examples include lathe, vernier calipers, and torque wrench). We mention this in particular because it is the only example in our material in which pronunciation received explicit focus.

Furthermore, we observed three instances in which the embedded tasks combined vocabulary with writing (S1, S3, and S7). In writing trajectories, vocabulary work will be embedded in various ways, but we focus on instances in which it is explicitly mentioned. In our material, this mainly occurred in the whole class introduction of tasks when teachers framed vocabulary as important for writing quality. In S1, the teacher introduced specific vocabulary as an important genre trait for the instruction manuals the students wrote, while in S3 and S7, the teachers described the ability to use appropriate and advanced 
vocabulary as a requirement to do well on the end-of-year exam. Furthermore, they framed the written assignments as opportunities to practice vocabulary skills. In S1 and S3, we also observed instances of teacher-student interactions about vocabulary that occurred as the students were writing. These instances did, however, involve a smaller number of students, typically on the initiative of the student.

It proved more challenging to give accurate descriptions of the way that vocabulary and speaking co-occurred in our material. We observed a great deal of speaking across all eight classrooms, sometimes mainly on the part of the teacher, but often also on the part of the students. However, few tasks or episodes involving vocabulary emerged as primarily about oral communication. Instead, they were typically incidents when students shared their answers to specific tasks in the initiation-response-feedback (IRF) format (i.e., the teacher checked the students' answers). One exception is S5, where we observed several longer stretches of classroom conversation. We will present the practices observed in S5 in the example section below (Section 3.2).

\subsection{Three Snapshots from the Material}

To provide more insight into how the overriding trends (Section 3.1) play out in our observations, we will present three snapshots from the material. These snapshots illustrate some of the dominant tendencies and capture interesting examples not easily covered in the structured presentations above. However, because they were selected to illustrate practices of particular interest to language teaching/learning in addition to the typical, they do not cover all the aspects addressed in Sections 3.1.1-3.1.3. Table 3 gives a more detailed overview of what the snapshots are examples of.

Table 3. Details about the observations described as snapshots.

\begin{tabular}{|c|c|c|c|c|c|c|c|c|c|}
\hline & \multicolumn{2}{|c|}{ Word Choice } & \multicolumn{3}{|c|}{ Organization } & \multicolumn{4}{|c|}{ Vocabulary Context } \\
\hline & \multirow{2}{*}{ Work } & \multirow{2}{*}{ Education } & \multirow{2}{*}{ Whole Class } & \multirow{2}{*}{ Group } & \multirow{2}{*}{ Individual } & \multicolumn{2}{|c|}{ Inter-Subject } & \multicolumn{2}{|c|}{ Intra-Subject } \\
\hline & & & & & & Explicit & Implicit & Separate & Embedded \\
\hline S2 & $\checkmark$ & & $\checkmark$ & & & $\checkmark$ & & $\checkmark$ & \\
\hline S5 & $\checkmark$ & & $\checkmark$ & & $\checkmark$ & $\checkmark$ & & & $\checkmark$ \\
\hline S8 & $\checkmark$ & & & & $\checkmark$ & $\checkmark$ & & $\checkmark$ & \\
\hline
\end{tabular}

\subsubsection{Snapshot 1: Vocational Orientation Curbs English Language Use}

We have classified this snapshot from S2 as an example of whole-class instruction targeting work-related vocabulary. Concerning the inter-subject level, this is an example of an explicit VO link, while at the intra-subject level, it illustrates a separate activity.

In S2, we observed how the teacher prepared his students for an upcoming English assessment where the students would describe the process of ATV assembly. The assessment itself was not part of the observed trajectory. To be able to perform well, the students would first need to learn relevant vocabulary, and the teacher had preselected target words, which he presented on digital flashcards. Words on his list included parts, such as shock absorber and front hub, and processes, such as frame production and bending by bulging. For each word, the teacher asked questions about the students' workshop experiences, and he offered additional information indicative of extensive technical knowledge. However, both teacher and students used Norwegian almost exclusively, and all technical explanations and interactions were all in Norwegian. English was only used in the actual translations of target vocabulary.

Of particular interest here is the way the teacher created an explicit VO link: there were clear bonds to an ongoing unit in the students' vocational subject, visible in the topic (ATV assembly), and in the teacher's rich descriptions of the target vocabulary. He gave detailed explanations of vehicle parts and construction processes and asked follow-up questions that tapped into the students' practical and technical competence. As an example, 
when introducing joining, the teacher had four students comment on the joining processes used for ATV assembly. However, while the teacher was able to build on the students' vocational content knowledge, all communication, including the technical discussions, was conducted in Norwegian, and English was never used beyond the word level. The observed interactions involved many relevant terms, and if the interactions had been conducted in English, they would have afforded opportunities to practice vocabulary in relevant communicative contexts.

The observation exemplifies how it is possible for English teachers to create strong inter-subject links where students can use terminology to talk about their own work and experiences. However, it is also an example of how teachers may struggle to balance vocational topics with language learning. Across our material, the choice to use mostly Norwegian was not very common, but it was found in S2 and S6.

\subsubsection{Snapshot 2: Vocabulary and Communication beyond the Word Level}

In S5, the episode we report on occurred halfway through our first observation. We have classified this snapshot as mainly an example of whole-class instruction, with some individual work. The students targeted work-related vocabulary, more specifically, safety equipment. Concerning the inter-subject level, this is an example of an explicit VO link, while at the intra-subject level, it is an example of an embedded activity in which vocabulary has a function in spoken interaction.

We observed how the teacher asked the students to write down examples of safety gear and protective clothing. They were told to use Norwegian only if they did not know or could not guess the word in English. After some minutes of individual work, the teacher started collecting words for a shared list. The first item mentioned was safety glasses. The teacher said this could also be a different word, and another student offered safety goggles. The teacher stated that safety googles are important to avoid getting splinters or swarf in the eyes and added a column to the blackboard where he wanted to write down why the various types of equipment are essential. The class then discussed where splinters or swarf come from and concluded that they are both hot and sharp. Four students engaged heavily in this discussion. After a while, the teacher continued collecting words:

Teacher: More for the list?

Filip: Safety boots

Teacher: Why are they safe?

Filip: Because if you drop a hammer on them, it won't hurt.

Teacher: Yes, but why? Why does it not hurt?

Filip: Because they have a steel tip

Teacher: What should we write on why?

Filip: So, I do not drop something on my feet, and it hurts?

Teacher: Yes, but it does not really protect you from dropping something, does it?

Filip: No ....

Teacher: So, we can put that safety boots are to protect from falling objects?

Filip: Yes!

The part of this observation we would like to unpack concerns the way the students were required to use domain knowledge to list and elaborate on vocabulary relating to safety equipment. As part of a health and safety certification mandatory in their vocational program, they had developed knowledge of workshop hazards and how to avoid them, such as by using safety equipment. The structure of the vocabulary activity allowed the students to use this knowledge not only to offer relevant vocabulary but also to engage in explaining the protective function of the various equipment. In this manner, the teacher and students used target vocabulary in communication beyond the word level, which we rarely saw in our material. The observation exemplifies how English teachers can create 
opportunities for L2 interactions in which target vocabulary is in active use while students take responsibility for identifying relevant vocabulary within a specific topic.

\subsubsection{Snapshot 3: An Opportunity to Practice Translation Strategies}

We have classified this snapshot from S8 as an example of individual instruction targeting work-related vocabulary. Concerning the inter-subject level, it has an explicit VO link, while at the intra-subject level, it is an example of a separate activity that only concerns word learning.

We observed how, as the first activity of the lesson, the students were asked to translate thirteen terms from Norwegian into English. These terms were, in their Norwegian form, key for understanding the current unit in the vocational subject. Most of the words were quite challenging to translate, some because they were linked to the specific organization of health services in Norway, others because they were compound words, while others were challenging because the students lacked the necessary background knowledge to understand the words and their significance. The students used several electronic and online dictionaries, and if these gave no definitive answers, they made guesses, which they then set out to verify using online sources. One student, for example, used Google Images and Wikipedia to verify her initial guess of how to translate sosial kompetanse ("social competence") into English. In addition, the teacher aided her students in the process of analyzing L1 words to achieve a better understanding of their meaning. Here is one example:

S9: I don't know how to translate samhandlingskompetanse [collaborative competence]

$\mathrm{T}$ : What does it mean in Norwegian? What is the essence of this word?

S9: I don't know. We haven't talked about it in our vocational subject yet.

T: [To everyone]: When you encounter a word you are unsure of, it is very helpful to think about the word in Norwegian. And if you do not know what it means in Norwegian, you can look it up and read about it in Norwegian before translating into English.

As a final part of this segment, the teacher asked the students to use digital flashcards that she had prepared to check their translations against hers. However, the teacher did not treat her own suggestions as final or the only possible options, telling her students that "if you disagree with the way I have translated something, let me know and we can discuss it." Our observations include examples of students who initiated such discussions.

In this classroom, we noticed how the students persisted in their translation work, and instead of giving up or asking the teacher for help (which we observed in many other instances), utilized a repertoire of strategies to identify suitable translations. We did not observe similar practices anywhere else. This observation exemplifies how students can become proficient and autonomous users of translation strategies, but because it was the only instance when we observed strategy use, it also suggests that students do not automatically develop the strategies they need.

\section{Discussion}

In this study, we have described characteristics of vocabulary work within a vocational orientation to L2 English teaching. The study is informed by Skarpaas and Hellekjær (2021), who found that English teachers in Norway described vocabulary work as a backbone of VO teaching. Our study supports this contention by establishing that vocabulary work indeed had a strong presence within the VO instruction that we analyzed. In the following, we discuss our findings, starting with word choice (Section 4.1), then organization (Section 4.2), and finally context (Section 4.3).

\subsection{Word Choice}

Regarding word choice within the VO approach, we found that the teachers prioritized terminology from the students' vocational programs. Using Nation's (2001) description 
of the levels of vocabulary (i.e., high-frequency words, academic vocabulary, technical vocabulary, and low-frequency words), we conclude that $\mathrm{VO}$ teaching mainly addresses technical vocabulary. In other words, most of the vocabulary concerns words that are part of the system of subject knowledge within a particular domain (Chung and Nation 2004). We also found evidence that some teachers take a broader approach to VO vocabulary, by including words to describe education and school systems. This vocabulary would typically be categorized as academic, using Nation's (2001) descriptions. Thus, the vocabulary taught under a VO heading can be classed as belonging to one of two categories: technical words to describe (future) work-related practices or academic words to describe education. Of these, the first category was by far the most common.

We take the priority given to work-related vocabulary as an indication that the teachers wanted to target words that may prove useful to their students in their future work life. In the classrooms we studied, the English teachers had typically preselected target words (see Snapshot 1), and we observed very few instances where students were involved in negotiating relevant words (Snapshot 2 provides one of those rare examples). From the perspective of teachers, it is clearly an advantage to preselect vocabulary, as it means they can-to some extent-remain in control of the learning sequence even with very little vocational background knowledge. However, as several others have described how language teachers struggle to identify which L2 words vocational students need to learn (Cowan 1974; Webb and Nation 2017; Widodo 2016), this is not necessarily an advantage from the perspective of student learning. To some degree, a teacher's ability to pinpoint what is relevant vocabulary will be determined by their domain content knowledge (Nagy and Townsend 2012) and the extent to which they collaborate with vocational teachers (Widodo 2016). We know from Skarpaas and Hellekjær (2021) that vocational English teachers in Norway rarely experience such collaborations and that they also struggle to comprehend the core content of their students' vocational educations. This raises the question of whether the teachers are in a position to select vocabulary that represents core aspects of their students' vocational learning. To ameliorate what can be seen as a problematic situation, we build on Alcina (2011), Fernádez et al. (2009), Chung and Nation (2003), and Nation (2001), whom all argue that there is no need for English teachers to be vocational experts to succeed in teaching vocational terminology. Instead, English teachers in vocational education can retain their role as language experts and focus on facilitating vocational language encounters. This would entail a practice of involving students in identifying central vocational topics and key terminology related to the topics in question. Rather than being the students' dictionaries, teachers can explain dictionary use, support the students' language awareness and require them to review their understanding of central vocational content by identifying key terms. Snapshot 2 gave one example of how this might function in practice.

\subsection{Organization}

Our second finding concerns classroom organization. We found that vocabulary work was included in whole-class instruction, group or pair work, and individual work. Of these, teacher-led whole-class conversations were the most common and found in all eight classrooms with explicit vocabulary focus. Typically, the conversations were instances of highly structured IRF sequences. Independent work was also common and included many instances of L1-L2 translation. Group or pair work could be identified in only half of the classrooms and was clearly outnumbered by the other two organizational forms.

Regardless of organizational form, most vocabulary tasks were highly structured, either by the teacher or by task instructions, and they rarely required independent reasoning. Webb and Nation (2017) argue that the quantifiable nature of vocabulary learning makes the progress of lexical development relatively clear compared to other language skills, which is something students tend to appreciate. In general, when translating a list of words into English, teachers and students might achieve a sense of quick progression as they check off words that have been satisfactorily translated. In our observations, the teachers typically helped students who struggled with their translations by offering the correct 
answer instead of supporting them in figuring it out on their own. This ensured (superficial) progress for everyone. In line with Webb and Nation (2017), we hypothesize that the highly organized structure of much vocabulary work, combined with this sense of progress, could explain why teachers perceived it to be a popular VO approach among vocational students (Skarpaas and Hellekjær 2021)

In this study, we found that when VO teaching trajectories include explicit attention to vocabulary, form-focused instruction, and to some degree comprehensible input, is prioritized over meaning-focused output and fluency development (i.e., the four strands, Nation 2001). We believe that this imbalance would be redressed by a shift in the instructional organization away from teacher-led whole-class instruction. We will also argue that because the material contains extensive use of L1-L2 translation, there is great but untapped potential to practice vocabulary strategies and to raise the students' language awareness. Both strategy practice and language awareness have been described as particularly important for students who have a great deal of English-language contact outside of school (Nation 2001; Schmitt 2017; Webb and Nation 2017). S8, which we presented in some detail in our third snapshot, provided the only example of how translation tasks can be utilized to develop students' autonomous use of language learning strategies. Here, the teacher developed a standard translation task to house explicit focus on how to use translation strategies independently, which she paired with an invitation to utilize vocational knowledge as a resource while engaging in the translations.

\subsection{Context}

The third and final finding concerns contextual variations in vocabulary teaching. We have described context using two parameters: inter- and intra-subject relationships. We argue that the findings in this study suggest that both aspects of context are important to realize the full potential of vocabulary teaching from a VO perspective.

Creating close inter-subject links between English and the students' vocational subjects is a practice that contributes toward framing English as a relevant part of vocational education, which is typically what educational stakeholders have called for when requesting an integration between general and vocational subjects (see Conroy and Walker 2000; European Centre for the Development of Vocational Training (CEDEFOP) (2019); Hoachlander 1999; NOU 2008:18 2008; Quinn 2013; Roberts et al. 2005; Vogt and Kantelinen 2012). Snapshots 1 (S2) and 2 (S5), where target words were anchored in a vocational unit, exemplify what this may look like in relation to vocabulary teaching. However, in Snapshot 1 , we also observed that on the intra-subject parameter, the vocabulary work occurred in isolated activities, with no opportunities for application to reading, writing, or speaking purposes. Webb and Chang (2015) argue that the application of newly encountered words is key to more durable long-term learning gains, and for the same reason, Nation (2007) urges teachers to develop a system to ensure the return to the same material several times over. On these grounds, we argue that in the case of S1 (and the other examples of isolated vocabulary practices), the conditions for vocabulary retention would be improved if the teacher planned for multiple encounters-preferably across the four language skills—with the same vocabulary within a short timeframe.

To develop comprehensive word knowledge, learners need to focus on form, meaning, and use and to practice the words receptively and productively (Nation 2001; Webb 2005). Our snapshot design cannot reveal whether target vocabulary was revisited outside of the observed trajectories, and it is, therefore, possible they were given more attention at a later date. However, we did observe complete trajectories, and within these trajectories, there were typically few opportunities for repeated use and few opportunities to use target vocabulary while producing output. Our study is not in a position to explain why this may be. Instead, we contend that although the students' vocational subjects are a good place to anchor vocabulary instruction, the vocational link must not overshadow the language aspect of vocabulary learning. With grounds in the previous research presented above, we suggest a need to balance the two aspects of context so that the engagement-supportive 
practices of VO do not hamper the language learning prospects of vocabulary activities. In sum, our study suggests that a potential means of improvement within VO vocabulary instruction is the extent to which it supports the development of speaking and writing skills, as well as the type of language awareness needed to understand nuances linked to meaning and use. Vocabulary work can become richer if teachers consider both the interand intra-subject aspects of the context in planning their activities.

\section{Concluding Remarks and Didactic Implications}

Through the investigation of twenty-three English L2 lessons in eight vocational classrooms, this study has identified aspects of $\mathrm{VO}$ vocabulary instruction that can be used to discuss why vocabulary is a favored part of VO teaching. Furthermore, the study has analyzed how teachers approach vocabulary and it has identified some debatable issues.

The main contribution of this study lies in the way it documents vocabulary practices within VO teaching. By observing multiple classrooms, the material provides grounds for future comparisons, such as with VO English teaching in other countries and contexts. Furthermore, the study is a contribution within the field of vocabulary instruction, where naturalistic observation studies of classroom practices are scarce.

In terms of motivating vocational students, an advantage of working with vocabulary within a VO frame is that it comes with a highly noticeable and easily accepted link between English and the students' vocational subject. When, for example, teachers ask their students to translate a list of tools found in the workshop, the task is recognizable both as an English language task and as relevant for vocational education.

In line with central voices in vocabulary research (Nation 2001; Schmitt 2017; Webb and Nation 2017), it is an important goal for students to become autonomous language learners and increase their word awareness (for example, ability to recognize words as technical and relate core meaning to technical meaning) as part of vocabulary instruction. Accordingly, a further advantage of linking vocabulary and relevant vocational issues-not fully utilized in the classrooms we observed-is that students can be involved in identifying key terms and in finding and testing strategies for arriving at precise terms. In this way, vocabulary tasks can support the students' language learning autonomy and release teachers from the responsibility of being vocational authorities.

Translating terms from L1 into L2-even if they are VO terms-will not automatically propel students' language competence forward. Instead, we suggest teachers prioritize activities that support student autonomy and help students develop a broader repertoire of vocabulary strategies. Furthermore, by embedding vocabulary work within a larger trajectory of, for example, writing and/or speaking, the students will have more opportunities to go beyond form to explore aspects of meaning and use.

Throughout our observations, the students seemed quite content with basic translation tasks. We can only speculate that this might be because it is a manageable task imbued with a sense of progress as words are translated. However, they are used to active ways of learning from their vocational subjects, and there is no reason to expect that the English subject would become less appealing if vocabulary activities prioritized autonomy, language exploration, and use over structured tasks.

Author Contributions: Conceptualization, K.G.S. and K.A.R.; Formal analysis, K.G.S.; Investigation, K.G.S.; Methodology, K.G.S. and K.A.R.; Project administration, K.G.S.; Resources, K.G.S.; Supervision, K.G.S.; Validation, K.G.S. and K.A.R.; Visualization, K.G.S.; Writing-original draft, K.G.S.; Writing-review and editing, K.G.S. and K.A.R. All authors have read and agreed to the published version of the manuscript.

Funding: This research received no external funding.

Institutional Review Board Statement: The study was conducted according to the guidelines of the Declaration of Helsinki and approved by Norwegian Centre for Research Data (protocol code 59328, date of approval: 16.03.2018).

Informed Consent Statement: Informed consent was obtained from all subjects involved in the study. 
Data Availability Statement: Data are not publicly available.

Acknowledgments: The authors would like to thank Glenn Ole Hellekjær for valuable feedback in the writing process.

Conflicts of Interest: The authors declare no conflict of interest.

\section{Appendix A. Example Fields Notes}

Example field notes 1, S4

Time: 0823-0840

The teacher starts the class by referring to the booklet from last week, saying that they are to finish their walk-through of correct answers. This becomes a sequence where two students partake, and the teacher is the main voice heard. She adds additional information on every bread/baked good they go through, and students are only invited to say one word here and there.

T: Find your booklet [waves the booklet from last week in the air]

S2: I am sorry, but I have lost it

T: Well, I do not have an extra copy, so then you will have to dig deep in your memory to remember.

They are to go through the answers for last week's glossary tasks. The teacher projects pictures of bread and baked goods onto the screen. First word (and picture) today is rundstykker 'rolls'. The teacher asks for the English name, a student says rolls. Teacher adds that in the English-speaking world rolls are usually eaten with food, not with cold cuts and spreads like we do in Norway.

Next picture is of a rugbrød 'rye bread'. One student gives the English name. Teacher says it is fairly coarse, and that barley and rye does not rise a whole lot. Therefore, it looks like a brick and is fairly heavy.

Next picture is a scone. A student gives the English name as scones. Teacher says it is something that used to be popular to make in elementary school in Norway, perhaps as the first thing to make in Mat og Helse 'food and health subject', because it is easy to make.

T: Do you know what scones are used for in England?

S3: They are eaten with jam or cheese or something.

T: Yes

Teacher proceeds to talk about clotted cream and that scones are eaten with tea in the afternoon. She also adds that proper scones should be baked so that you do not need a knife to cut them, you can simply twist them.

Next picture is of sourdough bread. Teacher asks what makes it different from other bread. One student says it is sour. Teacher says not necessarily in the flavor. A student says something about the way it is made, and the teacher agrees [I did not quite catch it].

Next is spelt bread. Teacher asks what makes it different from a regular loaf of bread. No one answers. Teacher eventually says you cannot tell from looking at it. However, it is the flour. Spelt is one of the original grains, it has more gluten in it and is therefore easier to bake with.

Example field notes 2, S7

Time: 0820-0848

The students sit quietly at their desks; the teacher is speaking. She introduces the project and says that it will end up with oral presentations. It is a continuation of what they did two weeks ago-now they will study two vocations in more depth. They should choose jobs they are interested in and might want in the future.

The teacher links the project to vocabulary, by saying that she often experiences that students do not use appropriate vocabulary when presenting their education or future jobs. She would therefore like to remind them of a few things related to vocabulary. She says that she wants them to take notes because this is important. The students get ready for 
taking notes (however my impression is that only one of them actually does it). The teacher writes on the board: Design, arts and crafts, not: going on a line, but "taking a course".

T: First and foremost, you are studying what in English is called Design, Arts and Crafts. So, when you refer to your study, use this title, and notice that in English you have upper case letters for each of the words. Often students tell me, they are going on a line called Design, Arts and Crafts. To a native speaker that sounds as if you are walking on a line, like this [mimes]. So, you can say that you are taking a course. A course is what they refer to as a line of study in English. Design, Arts and Crafts is one course in the vocational programme in Norway.

Then, the teacher goes through some other words on the board. The first one is 'vocational'. She says this is a word they have encountered earlier this autumn and asks if anyone remember what it means. No one answers, and the teacher says it means 'yrkesfalig'. She states that it is a very useful term for them to know. The next word is 'apprentice'.

T: Also, when you have studied here for two years, you may become an 'apprentice', what is that?

S1: [hand up]

T: Yes

S1: Skal jeg si det på norsk eller engelsk? [Should I answer in Norwegian or English?]

$\mathrm{T}$ : Si det på norsk, oversettelsen [Say it in Norwegian, the translation]

S1: Lærling da [Apprentice, then]

The next word is 'work placement', which the teacher explains herself. Then she mentions 'skills' and talks a bit about skills and 'competences' herself. She says that at the end of an apprenticeship, if you prove your competences you will get a 'diploma', or 'fagbrev'.

The teacher repeats that she wants the students to write the words down (they are all written on the board now), because students are very often not successful when they attempt to translate words that have to do with the Norwegian educational system into English. She also stresses that she would like to hear these words in the presentation.

\section{Appendix B. Themes, Descriptions, and Examples}

Table A1. Coding scheme with examples.

\begin{tabular}{|c|c|c|c|}
\hline Theme & Sub-Category & Descriptions & Example \\
\hline \multirow[t]{2}{*}{$\begin{array}{l}\text { Instruction with } \\
\text { explicit attention } \\
\text { to vocabulary }\end{array}$} & Yes & $\begin{array}{l}\text { The field notes report } \\
\text { explicit attention to } \\
\text { vocabulary in (a) the } \\
\text { teacher's framing of } \\
\text { task/learning outcome } \\
\text { and/or (b) the activities } \\
\text { the teacher initiate as part } \\
\text { of a task. }\end{array}$ & $\begin{array}{l}\text { (a) The teacher frames } \\
\text { vocabulary as a central } \\
\text { genre trait for instruction } \\
\text { manuals, making attention } \\
\text { to vocabulary a } \\
\text { requirement as the students } \\
\text { write manuals (S1). } \\
\text { (b) Students label the parts } \\
\text { of an all-terrain vehicle in a } \\
\text { visual mind map (S2). }\end{array}$ \\
\hline & No & $\begin{array}{l}\text { The field notes report no } \\
\text { explicit attention to } \\
\text { vocabulary as part of the } \\
\text { observed instruction. }\end{array}$ & $\begin{array}{l}\text { Students prepared and } \\
\text { presented talks about } \\
\text { music therapy for dementia } \\
\text { patients (S10, not included). }\end{array}$ \\
\hline
\end{tabular}


Table A1. Cont.

\begin{tabular}{|c|c|c|c|}
\hline Theme & Sub-Category & Descriptions & Example \\
\hline \multirow[b]{2}{*}{ Word choice } & $\begin{array}{l}\text { Anchored in } \\
\text { work }\end{array}$ & $\begin{array}{c}\text { Vocabulary to describe } \\
\text { own work }\end{array}$ & $\begin{array}{l}\text { Students talk about safety } \\
\text { equipment and protective } \\
\text { gear necessary to keep safe } \\
\text { the workshop (S5). }\end{array}$ \\
\hline & $\begin{array}{l}\text { Anchored in } \\
\text { education }\end{array}$ & $\begin{array}{l}\text { Vocabulary to describe } \\
\text { own education }\end{array}$ & $\begin{array}{l}\text { After the students have } \\
\text { worked with a gap-fill } \\
\text { exercise to describe their } \\
\text { own education program, } \\
\text { the teacher proceeds to test } \\
\text { their retention of central } \\
\text { education terms (S3). }\end{array}$ \\
\hline \multirow{3}{*}{ Organization } & Whole class & $\begin{array}{l}\text { Teacher and students } \\
\text { concurrently direct their } \\
\text { attention to the same } \\
\text { information, task or issue. } \\
\text { Teacher is typically } \\
\text { responsible for pace and } \\
\text { structure. }\end{array}$ & $\begin{array}{l}\text { In a whole-class format, } \\
\text { teacher asked the students } \\
\text { to list tools they had used } \\
\text { in the workshop (S6). }\end{array}$ \\
\hline & Group/pair & $\begin{array}{l}\text { Students work together, } \\
\text { two or more, to solve } \\
\text { tasks. The teacher offers } \\
\text { his / her support } \\
\text { as needed. }\end{array}$ & $\begin{array}{l}\text { Students played an online } \\
\text { vocabulary game, } \\
\text { competing against each } \\
\text { other in teams of three (S2 } \\
\text { and S3). }\end{array}$ \\
\hline & Individual & $\begin{array}{c}\text { Students work alone to } \\
\text { solve tasks. The teacher } \\
\text { offers his/her support } \\
\text { as needed. }\end{array}$ & $\begin{array}{l}\text { Students worked } \\
\text { individually to translate a } \\
\text { list of current focus terms } \\
\text { (L1) from their vocational } \\
\text { subject (S8) }\end{array}$ \\
\hline \multirow{2}{*}{$\begin{array}{c}\text { Vocabulary } \\
\text { context: } \\
\text { Inter-subject level }\end{array}$} & Explicit & $\begin{array}{l}\text { Explicit when observed } \\
\text { instruction had expressed } \\
\text { links to current (or past) } \\
\text { units of the students' } \\
\text { vocational subjects }\end{array}$ & $\begin{array}{l}\text { Students wrote instruction } \\
\text { manuals describing how to } \\
\text { operate a machine they had } \\
\text { used as part of their } \\
\text { vocational education (S1). }\end{array}$ \\
\hline & Implicit & $\begin{array}{l}\text { Implicit when there is no } \\
\text { evidence of links between } \\
\text { observed English } \\
\text { instruction and current } \\
\text { (or past) units of the } \\
\text { vocational subjects. }\end{array}$ & $\begin{array}{l}\text { First-year students read } \\
\text { about occupations they } \\
\text { might choose to qualify for } \\
\text { in their second year of } \\
\text { upper secondary } \\
\text { school (S7). }\end{array}$ \\
\hline \multirow{2}{*}{$\begin{array}{c}\text { Vocabulary } \\
\text { context: } \\
\text { Intra-subject level }\end{array}$} & Separate & $\begin{array}{l}\text { The purpose of the } \\
\text { activity is to learn the } \\
\text { words. The words are not } \\
\text { utilized for any other } \\
\text { purpose in the observed } \\
\text { trajectory. }\end{array}$ & $\begin{array}{l}\text { Students translated } \\
\text { baking-related terms from } \\
\text { Norwegian into } \\
\text { English (S4). }\end{array}$ \\
\hline & Embedded & $\begin{array}{l}\text { The attention to words is } \\
\text { framed as necessary for } \\
\text { completing a larger task }\end{array}$ & $\begin{array}{l}\text { Students write } \\
\text { presentations comparing } \\
\text { two occupations in terms of } \\
\text { education and work tasks. } \\
\text { The teacher has framed } \\
\text { specific vocabulary, } \\
\text { particularly to describe } \\
\text { education, as important for } \\
\text { goal attainment (S7) }\end{array}$ \\
\hline
\end{tabular}




\section{Appendix C. Overview of How Vocabulary Instruction Was Structured in the Observed Classrooms}

Table A2. Overview of how vocabulary instruction was structured in the observed classrooms.

\begin{tabular}{ccccccccc}
\hline & S1 & S2 & S3 & S4 & S5 & S6 & S7 & S8 \\
\hline Whole class & $\checkmark$ & $\checkmark$ & $\checkmark$ & $\checkmark$ & $\checkmark$ & $\checkmark$ & $\checkmark$ & $\checkmark$ \\
\hline Group or pair & & $\checkmark$ & $\checkmark$ & & & $\checkmark$ & $\checkmark$ & $\checkmark$ \\
\hline Individual & $\checkmark$ & & $\checkmark$ & $\checkmark$ & $\checkmark$ & $\checkmark$ & $\checkmark$ \\
\hline
\end{tabular}

\section{References}

Abbott, Ian. 1997. Why Do We Have to Do Key Skills? Student Views about General National Vocational Qualifications. Journal of Vocational Education and Training 49: 617-30. [CrossRef]

Alcina, Amparo. 2011. Teaching and Learning Terminology: New Strategies and Methods. In Teaching and Learning Terminology: New Strategies and Methods. Edited by Amparo Alcina. Amsterdam and Philadelphia: John Benjamins Publishing Company, pp. 1-10.

Braun, Virginia, and Victoria Clarke. 2012. Thematic analysis. In APA Handbook of Research Methods in Psychology, Volume 2. Research Designs: Quantitative, Qualitative, Neuropsychological, and Biological. Edited by Harris Cooper, Paul Camic, Debora Long, Abigail T. Panter, David Rindskopf and Kenneth Sher. Washington, DC: American Psychological Association, pp. 57-71.

Brevik, Lisbeth M., and Thea Holm. Forthcoming. Affinity and the Classroom: Informal and Formal L2 Learning [Manuscript submitted for publication]. ELT Journal. in press.

Brewer, Laura, and Paul Comyn. 2015. Integrating Core Work Skills into TVET Systems: Six Country Case Studies. Geneva: International Labour Organization. Available online: http:/ /hdl.voced.edu.au/10707/406014 (accessed on 24 August 2021).

Cabau, Béatrice. 2009. The Irresistible Rise and Hegemony of a Linguistic Fortress: English Teaching in Sweden. International Multilingual Research Journal 3: 134-52. [CrossRef]

Chung, Teresa Mihwa, and Ian Stephen Paul Nation. 2003. Technical Vocabulary in Specialised Texts. Reading in a Foreign Language 15: 103-16. Available online: http:/ / hdl.handle.net/10125/66770 (accessed on 2 September 2021).

Chung, Teresa Mihwa, and Ian Stephen Paul Nation. 2004. Identifying Technical Vocabulary. System 32: 251-63. [CrossRef]

Cobb, Tom. 2007. Computing the Vocabulary Demands of L2 Reading. Language Learning and Technology 11: 38-63.

Conroy, Carol A., and Nancy J. Walker. 2000. An Examination of Integration of Academic and Vocational Subject Matter in the Aquaculture Classroom. Journal of Agricultural Education 41: 54-64. [CrossRef]

Cowan, J. R. 1974. Lexical and Syntactic Research for the Design of EFL Reading Materials. TESOL Quarterly 8: 389-99. [CrossRef]

Coxhead, Averil. 2018. Vocabulary and English for Specific Purposes Research. London and New York: Routledge.

Coyle, Do. 2010. "Foreword". In CLIL in Spain: Implementation, Results and Teacher Training. Edited by David Lasagabaster and Yolanda Ruiz de Zarobe. Cambridge: Cambridge Scholars Publishing, pp. vii-viii.

De Wilde, Vanessa, and June Eyckmans. 2017. Game On! Young Learners' Incidental Language Learning of English Prior to Instruction. Studies in Second Language Learning and Teaching 7: 673-94. [CrossRef]

European Centre for the Development of Vocational Training (CEDEFOP). 2019. Practical Application of Theoretical Courses. Available online: https: / / www.cedefop.europa.eu/en/toolkits/vet-toolkit-tackling-early-leaving/intervention-approaches / practicalapplication-theoretical-courses (accessed on 16 September 2021).

Fernádez, Trinidad, Maria Aurora Flórez de la Colina, and Pam Peters. 2009. Terminology and Terminography for Architecture and Building Construction. Terminology 15: 10-36. [CrossRef]

Grubb, W. Norton. 2006. Vocational Education and Training: Issues for a Thematic Review. Paris: Organisation for Economic Co-operation and Development (OECD).

Hellne-Halvorsen, Ellen Beate, Leif Christian Lahn, and Hæge Nore. 2021. Writing Competences in Norwegian Vocational Education and Training: How Students and Apprentices Express their Professional Competences. Vocations and Learning 14: 243-64. [CrossRef]

Hiim, Hilde. 2014. Yrkesretting av fellesfag. Yrkesfaglærerens og elevers erfaringer i forsøk med yrkesretting av fellesfag [“Vocational Orientation of Common Core Subjects: Vocational Teachers and Students' Experiences with Vocational Orientation of Common Core Subjects"]. In Profesjonsrettet Pedagogikk 8-13. Edited by May Britt Postholm and Tom Tiller. Oslo: Cappelen Damm Akademisk, pp. 178-99.

Hiim, Hilde. 2017. Ensuring Curriculum Relevance in Vocational Education and Training: Epistemological Perspectives in a Curriculum Research Project. International Journal for Research in Vocational Education and Training 4: 1-19. [CrossRef]

Hoachlander, Gary. 1999. Integrating Academic and Vocational Curriculum-Why Is Theory So Hard To Practice? Available online: http: / / files.eric.ed.gov/fulltext/ED433454.pdf (accessed on 24 August 2021).

Hulstijn, Jan H., and Batia Laufer. 2001. Some Empirical Evidence for the Involvement Load Hypothesis in Vocabulary Acquisition. Language Learning 51: 539-58. [CrossRef]

Hyland, Ken. 2007. English for Specific Purposes. In International Handok of English Language Teaching. Edited by Jim Cummins and Chris Davison. Boston: Springer, pp. 391-402. 
Jensen, Signe H. 2017. Gaming as an English Language Learning Resource among Young Children in Denmark. Calico Journal $34:$ 1-19. [CrossRef]

Johansson, Stig. 1978. Studies of Error Gravity: Native Reactions to Errors Produced by Swedish Learners of English. Göteborg: Acta Universitatis Gothoburgensis.

Knoch, Ute. 2014. Using Subject Specialists to Validate an ESP Rating Scale: The Case of the International Civil Aviation Organization (ICAO) Rating Scale. English for Specific Purposes 33: 77-86. [CrossRef]

Kuppens, An H. 2010. Incidental Foreign Language Acquisition from Media Exposure. Learning, Media and Technology 35: 65-85. [CrossRef]

Laufer, Batia. 2010. Form Focused Instruction in Second Language Vocabulary Learning. In Further Insights into Non-Native Vocabulary Teaching and Learning. Edited by Ruben Chacón-Beltrán, Christian Abello-Contesse and Maria del Mar Torreblanca-López. Bristol: Multilingual Matters, pp. 15-27.

Laufer, Batia, and Geke C. Ravenhorst-Kalovski. 2010. Lexical Threshold Revisited: Lexical Text Coverage, Learners' Vocabulary Size and Reading Comprehension. Reading in a Foreign Language 22: 15-30.

Laufer, Batia, and Jan H. Hulstijn. 2001. Incidental Vocabulary Acquisition in a Second Language: The Construct of Task-Induced Involvement. Applied Linguistics 22: 1-26. [CrossRef]

Lindgren, Eva, and Carmen Muñoz. 2013. The Influence of Exposure, Parents, and Linguistic Distance on Young European Learners' Foreign Language Comprehension. International Journal of Multilingualism 10: 105-29. [CrossRef]

Liu, Dilin, and Lei Lei. 2020. Technical Vocabulary. In The Routledge Handbook of Vocabulary Studies. Edited by Stuart Webb. London and New York: Routledge, pp. 111-24.

Llach, Maria Pilar Augustin. 2011. Lexical Errors and Accuracy in Foreign Language Writing. Clevedon: Multilingual Matters.

Mouzakitis, Georg S. 2010. The Role of Vocational Education and Training Curricula in Economic Development. Procedia-Social and Behavioral Sciences 2: 3914-20. [CrossRef]

Nagy, William, and Dianna Townsend. 2012. Words as Tools: Learning Academic Vocabulary as Language Acquisition. Reading Research Quarterly 47: 91-108. [CrossRef]

Nation, Ian Stephen Paul. 2001. Learning Vocabulary in Another Language. Cambridge: Cambridge University Press.

Nation, Ian Stephen Paul. 2007. The Four Strands. Innovation in Language Learning and Teaching 1: 2-13. [CrossRef]

Nation, Ian Stephen Paul. 2017. How Vocabulary is Learned. Indonesian Journal of English Language Teaching 12: 1-14. [CrossRef]

Nation, Ian Stephen Paul. 2020a. Is It Worth Teaching Vocabulary? TESOL Journal 12: 1-9. [CrossRef]

Norwegian Directorate for Education and Training [UDIR]. 2006. English Curriculum LK06 (LK06, ENG1-03). Available online: https: / / www.udir.no/k106/ENG1-03?lplang=eng (accessed on 1 October 2021).

Norwegian Directorate for Education and Training [UDIR]. 2019. Curriculum in English (ENG01-04). Available online: https://www. udir.no/lk20/eng01-04?lang=eng (accessed on 10 October 2021).

Norwegian Directorate for Education and Training [UDIR]. 2020. Norwegian Vocational Education and Training (VET). Available online: https:/ / www.udir.no/in-english/norwegian-vocational-education-and-training/ (accessed on 10 October 2021).

Norwegian Directorate for Education and Training [UDIR]. 2021. Elevtall i Videregående Skole-Utdanningsprogram og Trinn [Student Numbers in Upper Secondary School by Study Programme and Year]. Available online: https:/ /www.udir.no/tall-og-forskning/statistikk/ statistikk-videregaende-skole/elevtall-i-videregaende-skole/elevtall-vgo-utdanningsprogram/ (accessed on 15 October 2021).

NOU 2008:18. 2008. Fagopplæring for Framtida (NOU 2008:18) [Vocational Training for the Future]. Oslo: Kunnskapsdepartementet. Available online: https:/ / www.regjeringen.no/no/dokumenter/nou-2008-18/id531933/ (accessed on 8 October 2021).

Qian, David, and Linda H. F. Lin. 2020. The Relationship between Vocabulary Knowledge and Language Proficiency. In The Routledge Handbook of Vocabulary Studies. Edited by Stuart Webb. London and New York: Routledge, pp. 66-80.

Quinn, Tammy T. 2013. An Investigation of Curriculum Integration in a Vocational School Setting: A Qualitative Study. Unpublished Doctoral dissertation, Northeastern University, Boston, MA, USA. Available online: https:/ / repository.library.northeastern.edu/ files/neu:1067 (accessed on 20 September 2021).

Regulations of the Education Act. 2006. Regulations of the Education Act (FOR-2006-06-23-724). Available online: https: / /lovdata.no/ dokument/SF/forskrift/2006-06-23-724 (accessed on 15 October 2021).

Rindal, Ulrikke. 2014. What is English? Acta Didactica Norge 8: 1-17. [CrossRef]

Rindal, Ulrikke, and Lisbeth M. Brevik. 2019. Introduction. In English Didactics in Norway-30 Years of Doctoral Research. Edited by Ulrikke Rindal and Lisbeth M. Brevik. Oslo: Universitetsforlaget, pp. 9-15.

Roberts, Celia, Mike Baynham, Paul Shrubshall Jessica Brittan, Bridget Cooper, Nancy Gidley, Violet Windsor, Jan Eldred, Sue Grief, Celine Castillino, and Margaret Walsh. 2005. Embedded Teaching and Learning of Adult Literacy, Numeracy and ESOL: Seven Case Studies. Available online: https:/ / dera.ioe.ac.uk/29832/ (accessed on 6 October 2021).

Schmitt, Norbert. 2017. Vocabulary: Principles and Practices 1. English Teaching Professional 109: 4-6.

Schmitt, Norbert, and Diane Schmitt. 2020. Vocabulary in Language Teaching. Cambridge: Cambridge University Press.

Shi, Limin, and David Qian. 2012. How Does Vocabulary Knowledge Affect Chinese EFL Learners' Writing Quality in Web-based Settings?-Evaluating the Relationships among Three Dimensions of Vocabulary Knowledge and Writing Quality. Chinese Journal of Applied Linguistics 35: 117-27. [CrossRef]

Skarpaas, Kaja Granum, and Glenn Ole Hellekjær. 2021. Vocational orientation-A supportive approach to teaching L2 English in upper secondary vocational programmes. International Journal of Educational Research Open 2: 100064. [CrossRef] 
Stæhr, Lars Stenius. 2008. Vocabulary Size and the Skills of Listening, Reading and Writing. The Language Learning Journal 36: 139-52. [CrossRef]

Sundqvist, Pia, and Liss Kerstin Sylvén. 2016. Extramural English in Teaching and Learning: From Theory and Research to Practice. London: Palgrave Macmillan.

Sweet, Richard. 2010. Upper Secondary Curriculum Structures in OECD Countries. Available online: http://hdl.voced.edu.au/10707/ 349112 (accessed on 6 October 2021).

Terry, Gareth, Nikki Hayfield, Victoria Clarke, and Virginia Braun. 2017. Thematic analysis. In The SAGE Handbook of Qualitative Research in Psychology. Edited by Carla Willig and Wendy Stainton-Rogers. London: SAGE Publications Ltd., pp. 17-37.

Vogt, Karin, and Ritva Kantelinen. 2012. Vocationally Oriented Language Learning Revisited. ELT Journal 67: 62-69. [CrossRef]

Webb, Stuart. 2005. Receptive and Productive Vocabulary Learning: The Effects of Reading and Writing on Word Knowledge. Studies in Second Language Acquisition 27: 33-52. [CrossRef]

Webb, Stuart, and Anna C.-S. Chang. 2015. Second Language Vocabulary Learning Through Extensive Reading with Audio Support: How Do Frequency and Distribution of Occurrence Affect Learning? Language Teaching Research 19: 667-86. [CrossRef]

Webb, Stuart, and Ian Stephen Paul Nation. 2017. How Vocabulary Is Learned. Oxford: Oxford University Press.

Widodo, Handoyo Puji. 2016. Teaching English for Specific Purposes (ESP): English for Vocational Purposes (EVP). In English Language Teaching Today: Linking Theory and Practice. Edited by Willy A. Renandya and Handoyo Puji Widodo. Cham: Springer International Publishing, pp. 277-91.

Woodward-Kron, Robyn. 2008. More Than Just Jargon-The Nature and Role of Specialist Language in Learning Disciplinary Knowledge. Journal of English for Academic Purposes 7: 234-49. [CrossRef] 